\title{
Hemostatic evaluation of rabbits envenomed with Bothrops alternatus treated with anti-bothropic serum, desmopressin and tranexamin acid $^{1}$
}

\author{
Warley G. Santos ${ }^{2}$, Rita C.F. Duarte ${ }^{2}$, Claudio R.S. Mattoso², \\ Gabriella M.L. Diamantino², Ana F.M. Botelho' (D), \\ Maria G. Carvalho ${ }^{2}$ and Marília M. Melo ${ }^{2 *}$ (iD
}

\begin{abstract}
Santos W.G.S., Duarte R.C.F., Mattoso C.R.S., Diamantino G.M.L., Botelho A.F.M., Carvalho M.G. \& Melo M. 2021. Hemostatic evaluation of rabbits envenomed with Bothrops alternatus treated with anti-bothropic serum, desmopressin and tranexamin acid. Pesquisa Veterinária Brasileira 41:e06639, 2021. Laboratório de Toxicologia Veterinária, Escola de Veterinária, Universidade Federal de Minas Gerais, Av. Antônio Carlos 6627, Belo Horizonte, MG 31270-901, Brazil. E-mail: mariliamm@ufmg.br

In Brazil, snakes from the Bothrops genus are responsible for thousands of accidents, and their venoms are mainly composed of proteolytic enzymes. Although the antibothropic serum produced by the Brazilian Institutes is remarkably efficient, more studies are necessary, especially in veterinary medicine. The venom contain enzymes and non-enzymatic proteins that interfere with hemostasis leading to hemorrhage or even thrombosis. Possible treatment associations with known bothropic antivenom were the reason for the development of the present study. The aim of this study was to evaluate hemostasis alterations caused by Bothrops alternatus venom in rabbits followed by treatments with anti-bothropic serum, tranexamic acid and desmopressin. Twenty New Zealand rabbits were distributed into five groups $(\mathrm{n}=4)$ that were experimentally envenomed with $150 \mathrm{mcg} / \mathrm{kg}$ of B. alternatus venom via intramuscular injection and treated as follow: Group 1 (G1) was the positive control and received venom and PBS/BSA; Group 2 (G2) was treated with tranexamic acid; Group 3 (G3) with desmopressin; Group 4 (G4) with tranexamic acid and anti-bothropic serum; and Group 5 (G5) with anti-bothropic serum and desmopressin. Blood samples were collected before venom administration, and one, four, eight and 12 hours after, for Partial activated partial thromboplastin time, Prothrombin Time, Thrombin Time and fibrinogen evaluation. Thrombin generation (TG) test was carried out with a pool of samples from final times (8 and $12 \mathrm{~h}$ ). At the end of $12 \mathrm{~h}$, all animals were euthanized and necropsy was conducted. Samples from muscle tissue, heart, lungs and kidney were analyzed. Classic coagulation tests showed no significant differences amongst groups and times. However, TG indicated that the venom causes a hypocoagulability state, which was not reversed by proposed treatments. Histology showed muscle inflammation, hemorrhage and necrosis, as well as hemorrhage in other tissues with no differences amongst groups. B. alternatus envenomation causes hypocoagulability detected by TG assay, but not through classical coagulation tests. The use of tranexamic acid and desmopressin for hemostasis stabilization after inoculation of the venom did not show advantage in coagulation restoration.
\end{abstract}

INDEX TERMS: Hemostasis, rabbits, Bothrops alternatus, anti-bothropic serum, desmopressin, tranexamin acid, coagulation, Viperidae envenomation, thrombin generation.

\footnotetext{
${ }^{1}$ Received on September 21, 2020.

Accepted for publication on December 3, 2020.

${ }^{2}$ Laboratório de Toxicologia Veterinária, Escola de Veterinária, Universidade Federal de Minas Gerais (UFMG), Av. Antônio Carlos 6627, Belo Horizonte, MG 31270-901, Brazil. *Corresponding author: mariliamm@ufmg.br
}

RESUMO.- [Avaliação hemostática de coelhos envenenados com Bothrops alternatus e tratados com soro antibotrópico, desmopressina e ácido tranexâmico.] No Brasil, as serpentes do gênero Bothrops são responsáveis por milhares de acidentes, e seus venenos são compostos principalmente de enzimas 
proteolíticas. Embora o soro antiofídico produzido pelos institutos brasileiros seja notavelmente eficiente, mais estudos são necessários, especialmente na medicina veterinária. 0 veneno contem enzimas e proteínas não-enzimáticas que interferem com a hemostasia levando a hemorragias ou trombose. A associação de outros tratamentos ao soro antibotrópico foi a razão para o desenvolvimento do presente estudo. 0 objetivo deste estudo foi avaliar as alterações da hemostasia causadas pelo veneno de Bothrops alternatus em coelhos, após tratamento com soro antibotrópico, ácido tranexâmico e desmopressina. Vinte coelhos da Nova Zelândia foram distribuídos em cinco grupos $(\mathrm{n}=4)$ que foram submetidos a experimentos com $150 \mathrm{mcg} / \mathrm{kg}$ de veneno de B. alternatus por injeção intramuscular. 0 Grupo 1 (G1) foi o controle positivo e recebeu veneno e PBS / BSA, enquanto o Grupo 2 (G2) foi tratado com ácido tranexâmico, o Grupo 3 (G3) com desmopressina, o Grupo 4 (G4) com ácido tranexâmico e soro antibotrópico, e o Grupo 5 (G5) com soro antibotrópico e desmopressina. As amostras de sangue foram coletadas antes da administração do veneno, e uma, quatro, oito e 12 horas após os tratamentos para realização de tempo de tromboplastina parcial ativada parcial (TTPa), tempo de protrombina (TP), tempo de trombina (TT) e mensuração de fibrinogênio. Para o ensaio de geração de trombina (TG) foi realizado com um pool de amostras nos tempos finais $(8$ e $12 \mathrm{~h}$ ). Ao final das $12 \mathrm{~h}$, todos os animais foram sacrificados e a necropsia foi realizada. Amostras de tecido muscular, coração, pulmões e rins foram analisadas. Os testes TTPa, TP, TT e fibrinogênio não mostraram diferenças significativas entre os grupos e os tempos. No entanto, o TG indicou que o veneno causa um estado de hipocoagulabilidade, que não foi revertido pelos tratamentos propostos. Na histologia, foram observadas inflamação muscular, hemorragia e necrose, além de hemorragia em outros tecidos, sem diferenças entre os grupos. 0 envenenamento por $B$. alternatus causa hipocoagulabilidade detectada mais precocemente pelo teste de geração de trombina. 0 uso de ácido tranexâmico e desmopressina para estabilização da hemostasia após a inoculação do veneno não mostrou vantagem na restauração da coagulação.

TERMOS DE INDEXAÇÃO: Hemostase, coelhos, Bothrops alternatus, soro antibotrópico, desmopressina, ácido tranexâmico, coagulação, envenenamento Viperidae, geração de trombina.

\section{INTRODUCTION}

Snakebites are a public health issue in tropical countries such as Brazil. Over 27.000 accidents are annually reported, with Bothrops being responsible for the majority of cases (Brasil 2017). However, in veterinary, the number of accidents is unknown, due to the difficulty of documented reports. Bothrops alternatus belongs to the Viperidae family and is mainly present in the South region of Brazil and Northeast of Argentina (Rocha \& Furtado 2005). The complex venom causes a series of pathological disturbances that may include local edema, hemorrhage, necrosis, blisters, systemic hemostasis disturbances, acute renal failure, shock and death (Rocha \& Furtado 2005, Garcia-Denegri et al. 2016, Mamede et al. 2016).

The main components of the venom responsible for coagulation disturbances are balterobin, a thrombin-like protein; bothroalternin, a C-Type lectin thrombin inhibitor and alternagin, a hemorrhagic metalloproteinase (Gould et al. 1990, Castro et al. 1998, Smolka et al. 1998). Balterobin have shown in vitro pro-coagulant potential (Smolka et al. 1998), through increase conversion of fibrinogen into fibrin. Prolonged stimulation, however, may consequently lead to defibrin(ogen)ation due to its consumption. Conversely, bothroalternin exerts thrombin inhibition, thus leading to reduced thrombin effect on platelet aggregation (Castro et al. 1998). The combined effect of pro and anti-coagulant agents in the venom aggravates systemic bleeding induced mainly by the action of metalloproteinases (SVMPs) on microvasculature (Gutiérrez et al. 2009).

Critical patients, in such cases, may benefit from treatment with antifibrinolytic drugs such as tranexamic acid. This is a synthetic analogue of lisin that significantly reduces fibrinolysis (McCormack 2012) that has been successfully used in surgeries involving intense blood loss (Wong et al. 2016, Suh et al. 2018). Desmopressin is another drug used for the treatment of coagulation disturbances. It is a synthetic analogue of the hormone vasopressin (Horstman et al. 1995). Besides its' diuretic effect, desmopressin is a potent vasoconstrictor and increases endothelial liberation of coagulation factor VIII and von Willebrand factor (Vilhardt et al. 1987).

In order to evaluate coagulation disturbances of the envenomation and the effects of such treatments, classic coagulation tests, such as prothrombin time and activated partial thromboplastin time are essential. They provide significant information to determine the best treatment options and prognosis. Patients who suffered such snakebites often present delayed coagulation times (Sano-Martins et al. 1994). However, these tests show little correlation to hemorrhagic events, unless a significant delay is present (Hemker et al. 2003). Then, to increase sensibility of coagulation proofs, thrombin generation test by Calibrated Automated Thrombogram (CAT) method was developed. This test quantifies thrombin generation in plasma continually during 60 minutes after the addition of tissue factor (TF), phospholipids and calcium, resulting in coagulation activation and subsequent generation of thrombin (Hemker et al. 2003, Espitia \& Fouassier 2015).

The aim of the present study was to evaluate hemostasis, through classic coagulation tests and thrombin generation, in rabbits experimentally envenomed by $B$. alternatus and treated with anti-bothropic serum, tranexamic acid and desmopressin. This is the first study that evaluates thrombin generation by CAT method following bothropic envenomation in comparison with classical coagulation tests and may provide important insights into its pathophysiology and treatment.

\section{MATERIALS AND METHODS}

Venom and antivenom preparation. The lyophilized venom of Bothrops alternatus was provided by the Venom Section of the "Fundação Ezequiel Dias" (FUNED). Stock solution was prepared in $50 \mathrm{mM}$ of sodium phosphate, $50 \mathrm{Mm} \mathrm{NaCl}, \mathrm{pH}$ 7.4. The final concentration was $2.0 \mathrm{mg} / \mathrm{mL}$. The bothopic antivenom (BAV) was produced by the hyperimmunization of horses with venoms from $B$. alternatus (12.5\%), Bothrops jararaca (50\%), Bothrops jararacuçu (12.5\%), Bothrops moojeni (12.5\%) and Bothrops neuwiedi $12.5 \%)$ was obtained from the hyperimmune plasmas processing section of FUNED Institute.

Experimental design. All of the animal procedures were performed with the approval of the Animal Care and Use Committee 
of “Universidade Federal de Minas Gerais" (274/2015). Male New Zealand rabbits, weighing approximately $3 \mathrm{~kg}$, were obtained from the Veterinary College Farm of UFMG, Brazil. A pilot study was conducted to determine the toxic dose of the venom, which caused clinical signs, hemostatic alterations and the presence of hemorrhagic halo without causing death. The determined dose was $150 \mathrm{mcg} / \mathrm{kg}$ of $B$. alternatus venom.

Twenty New Zealand male rabbits (Oryctolagus cuniculus), were randomly distributed into five groups $(n=4)(G 1, G 2, G 3, G 4, G 5)$. All groups were experimentally envenomed with $150 \mathrm{mcg} / \mathrm{kg}$ of $B$. alternatus venom diluted in Phosphate Buffered Saline with Bovine Albumin Serum (PBS/BSA) at $0.1 \%$ via superficial intramuscular injection at the left thigh. Group 1 (G1) was the positive control and received venom and PBS/BSA, while groups 2 to 5 received different treatments. G2 was treated with tranexamic acid (25mg/ kg) (NIKKHO Laboratory, Brazil) (Pabinger et al. 2017), G3 with desmopressin $(0.3 \mathrm{mcg} / \mathrm{kg}$ ) (Ferring, São Paulo, Brazil) (Deloughery 2015), G4 with both tranexamic acid ( $25 \mathrm{mg} / \mathrm{kg}$ ) and anti-bothropic serum $(0.25 \mathrm{ml} /$ animal) and groups 5 (G5) with both anti-bothropic serum $(0.25 \mathrm{mg} / \mathrm{animal})$ and desmopressin $(0.3 \mathrm{mcg} / \mathrm{kg})$.

All animals were anesthetized on the day before with midazolam (1 $\mathrm{mg} / \mathrm{kg} \mathrm{IM})$, ketamine $(35 \mathrm{mg} / \mathrm{kg} \mathrm{IM})$ and xylazine $(3.5 \mathrm{mg} / \mathrm{kg} \mathrm{IM})$ for the insertion of a central venous catheter in the right jugular vein. Blood samples $(3 \mathrm{ml})$ were collected from the catheter before (T0) and after treatments at $1 \mathrm{~h}$ (T1), 4h (T4), 8h (T8) and 12h (T12) in tubes with sodium citrate (BD Vacutainer ${ }^{\circledR}$ ). At the end of $12 \mathrm{~h}$, all animals were euthanized with $150 \mathrm{mg} / \mathrm{kg}$ thiopental IV (Cristalia ${ }^{\circledR}$ ).

Coagulation tests. Blood samples were collected using Vacutainer ${ }^{\circledR}$ (Becton-Dickinson) tubes containing 3.2\% buffered sodium citrate and separated by double centrifugation at room temperature within $2 \mathrm{~h}$ of blood collection. Firstly, tubes containing blood samples were centrifuged at $1100 \times \mathrm{g}$ for $15 \mathrm{~min}$ and the supernatant (plasma) was aspirated carefully with a pipette, thereby staying $1 \mathrm{~cm}$ away from the buffy coat. Then plasma samples were centrifuged again, in plastic tubes, at $1100 \times \mathrm{g}$ for $15 \mathrm{~min}$ to obtain plasma with a platelet count less than $10,000 / \mathrm{mm}^{3}$. Plasma samples were pooled and aliquoted, and then stored at $-80^{\circ} \mathrm{C}$ until use. Sodium citrate platelet poor plasma from all five experimental samples (T0, T1, T4, T8, T12) were used to determine activated partial thromboplastin time (APTT), prothrombin time (PT), thrombin time (TT) and fibrinogen utilizing commercial kits (Clot Biodiagnóstica ${ }^{\circledR}$ ) with the aid of a coagulometer (Clot Timer ${ }^{\circledR}$, Clot, Brazil).

Thrombin generation. Thrombin generation test was conducted from the pool of cytrate platelet-poor plasma of each group at T8 and T12 times. Additionally, a pool at T0 was used as control processed in duplicates. Thrombin generation was measured by CAT method (Thrombinoscope BV ${ }^{\circledR}$, Maastricht, Netherlands), with $80 \mu \mathrm{m}$ pool of citratado platelet poor plasma. Reagents were purchased from Stago ${ }^{\circledR}\left(\alpha^{2}\right.$ M-Thrombin Calibrator reagent, PPP-Reagent Low ${ }^{\circledR}-1$ pM, PPP-Reagent High $^{\circledR}-5 \mathrm{pM}$ and FLUCA-Fluorescent substrate-CaCl${ }_{2}$, France). Thrombinoscope ${ }^{\circledR}$ software was used to calculate thrombin generation parameters. Thrombin generation was expressed by the following parameters: endogenous thrombin potential (ETP), lagtime, peak, and time to peak (ttPeak).

Histopathology. Following euthanasia, all animals were necropsied. Macroscopic evaluation was conducted and samples were collected in formalin $10 \%$ from the muscle site of inoculation, heart, liver, lungs and kidneys for microscopic analysis. All samples were processed by routine histological technique and stained with hematoxylin and eosin (HE).

Statistical analysis. Data are presented as means \pm SD. Normality of data distribution was evaluated using Shapiro-Wilk's test. Statistical significance between groups and times were determined by ANOVA, followed by Tukey's test. Significance was set at $P<0.05$. Data were analyzed using Statistical Analysis System (SAS).

\section{RESULTS}

\section{Thrombin generation}

TG parameters (lagtime; endogenous thrombin potential (ETP); peak and time to peak (ttPeak) at T8 and T12 are presented in Table 1-3. Overall, Bothrops alternatus venom decreased the values of ETP and peak, with prolonged ttPeak and lagtime. The highest observed results were from G3 $(B$. alternatus + desmopressin) at T8 and T12, while G4 was closest to negative control group. ETP values were far superior in negative control group when compared to all groups at both times. Similar results were found for Peak values. Time to peak was slightly prolonged at $\mathrm{T} 8$; and severely prolonged at T12, except for G1 (B. alternatus + PBSA/BSA) that remained similar to control group.

\section{Coagulation tests}

No significant differences were observed in classical coagulation tests: APTT, PT, TT and fibrinogen amongst times and groups, remaining within the normal range value for the species as shown in Table 4 and 5.

\section{Pathological findings}

Macroscopic evaluation following euthanasia showed that all animals whom had received venom presented extensive muscular damage characterized by focal hemorrhage, moderate to intense, gravitating through the thigh. Multifocal moderate lung hemorrhage was visible in animals from $\mathrm{G} 2$ ( $B$. alternatus + tranexamic acid) and G5 (B. alternatus + desmopressin +

Table 1. Thrombin generation of rabbits experimentally envenomed with Bothrops alternatus treated with tranexamic acid and desmopressin isolated or with anti-bothropic serum, eight and 12 hours after treatments

\begin{tabular}{|c|c|c|c|c|c|c|c|c|c|c|c|}
\hline \multirow{2}{*}{ Parameters } & \multirow{2}{*}{ Control } & G1 & G1 & G2 & G2 & G3 & G3 & G4 & G4 & G5 & G5 \\
\hline & & $8 \mathrm{~h}$ & $12 \mathrm{~h}$ & $8 \mathrm{~h}$ & $12 \mathrm{~h}$ & $8 \mathrm{~h}$ & $12 \mathrm{~h}$ & $8 \mathrm{~h}$ & $12 \mathrm{~h}$ & $8 \mathrm{~h}$ & $12 \mathrm{~h}$ \\
\hline Lagtime (min) & $2.6 \pm 0.6$ & 2.8 & 3.3 & 2.8 & 3.7 & 3.8 & 6.0 & 2.1 & 3.0 & 2.5 & 3.0 \\
\hline ETP $(\mathrm{nM} \bullet \min )$ & $390.1 \pm 1.0$ & 254.5 & 221.4 & 282.5 & 189.7 & 287.4 & 91.9 & 293.4 & 220.4 & 301.7 & 321.2 \\
\hline Peak (nM) & $106.4 \pm 15.8$ & 62.5 & 52.5 & 54.3 & 33.0 & 58.7 & 11.1 & 59.4 & 28.6 & 70.8 & 37.3 \\
\hline ttPeak (min) & $5.1 \pm 0.8$ & 5.1 & 5.7 & 4.8 & 6.3 & 6.1 & 10.3 & 5.5 & 7.0 & 4.8 & 7.7 \\
\hline
\end{tabular}

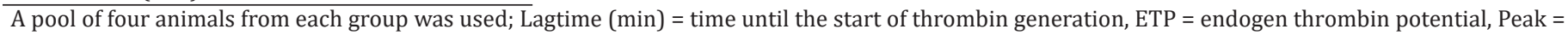

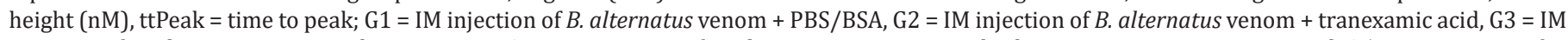

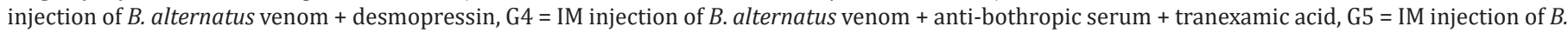
alternatus venom + anti-bothropic serum + desmopressin. 
anti-bothropic serum); multifocal discrete kidney hemorrhage was only observed in one animal from G4 (B. alternatus + tranexamic acid + anti-bothropic serum) and discrete focal heart hemorrhage was only visible in one animal from G2 and one from G3. Liver of all poisoned animals presented discrete congestion.

Microscopic evaluation of local muscle tissue of all envenomed animals showed focal flocular necrosis, associated with moderate hemorrhage, heterophil infiltration and intense edema. Muscle cells were eosinophilic, with loss of striation and angularity, followed by cytoplasm fragmentation, characterizing multifocal heterophilic necro-hemorrhagic myositis. No visible differences were detected amongst groups. Lung samples revealed discrete hemorrhage in animals from groups G1 (B. alternatus), G2 (B. alternatus + tranexamic acid), G4 (B. alternatus + tranexamic acid + anti-bothropic serum), G5 (B. alternatus + desmopressin + anti-bothropic serum). Microscopic kidney evaluation showed deposition of protein material in the tubular lumen of animals from groups G1, G2, G4 and G5. Evaluation of heart tissue showed minor focal hemorrhage in one animal from G2 and one from G3 (as observed macroscopically).

\section{DISCUSSION}

Bothrops envenomation, similar to other snakes, may cause severe coagulation disturbances that contribute to aggravating clinical signs and death (Bucaretchi et al. 2001, Núñez et al. 2004, Senise et al. 2015). Although serum treatment is the gold standard, new therapies that support hemostasis equilibrium are important to complement traditional antivenom therapy (Miranda et al. 2014). Tranexamic acid and desmopressin treatment in the present study were used due to their potential benefits in coagulation stability.

Considering the importance of such envenomation, our study evaluated both classic coagulation tests, including TP, TT, APTT and fibrinogen analysis as well as the thrombin generation by CAT method. Patients who suffered severe bothropic snakebites often present higher coagulation times. Before antivenom administration, it is estimated that $60.7 \%$ of patients have blood coagulation disorders, including $39.3 \%$ that show non-coagulable blood (Bucaretchi et al. 2001). Classic tests in the present study however remained unchanged in all groups at times evaluated. Such existing classic techniques are not sensitive to all stages of hemostasis, especially to detect

Table 2. Mean values and standard variation of activated partial thromboplastin time (APTT), prothrombin time (PT) and thrombin time (TT) of rabbits experimentally envenomed with Bothrops alternatus treated with anti-bothropic serum, tranexamic acid and desmopressin

\begin{tabular}{|c|c|c|c|c|c|c|}
\hline Tests & Time & G1 & G2 & G3 & G4 & G5 \\
\hline \multirow[t]{4}{*}{ APTT(s) } & T0 & $16.46 \pm 2.36$ & $10.75 \pm 3.80$ & $12.64 \pm 2.79$ & $14.08 \pm 1.06$ & $17.88 \pm 0.75$ \\
\hline & $\mathrm{T} 1$ & $20.15 \pm 5.57$ & $12.69 \pm 5.69$ & $12.30 \pm 2.63$ & $12.44 \pm 1.69$ & $14.69 \pm 2.04$ \\
\hline & $\mathrm{T} 4$ & $21.32 \pm 4.75$ & $17.16 \pm 6.03$ & $18.39 \pm 5.54$ & $15.19 \pm 1.49$ & $16.54 \pm 0.89$ \\
\hline & $\mathrm{T} 12$ & $19.95 \pm 7.48$ & $18.59 \pm 3.49$ & $13.73 \pm 7.24$ & $15.02 \pm 2.202$ & $15.81 \pm 3.51$ \\
\hline \multirow[t]{3}{*}{$\mathrm{PT}(\mathrm{s})$} & T0 & $8.49 \pm 1.19$ & $8.05 \pm 0.58$ & $9.83 \pm 0.20$ & $8.55 \pm 0.90$ & $9.31 \pm 1.04$ \\
\hline & T8 & $8.94 \pm 0.64$ & $8.20 \pm 0.60$ & $9.56 \pm 0.71$ & $8.29 \pm 1.31$ & $8.13 \pm 0.93$ \\
\hline & $\mathrm{T} 12$ & $8.73 \pm 0.75$ & $8.61 \pm 0.49$ & $10.18 \pm 0.96$ & $7.83 \pm 0.79$ & $7.53 \pm 0.66$ \\
\hline \multirow[t]{3}{*}{$\mathrm{TT}(\mathrm{s})$} & T0 & $8.59 \pm 0.93$ & $8.41 \pm 0.49$ & $8.51 \pm 1.32$ & $7.40 \pm 0.30$ & $7.44 \pm 0.29$ \\
\hline & $\mathrm{T} 1$ & $9.34 \pm 1.58$ & $8.88 \pm 0.48$ & $8.54 \pm 0.91$ & $8.50 \pm 0.38$ & $7.39 \pm 0.26$ \\
\hline & $\mathrm{T} 4$ & $8.63 \pm 0.75$ & $8.53 \pm 0.54$ & $8.28 \pm 1.19$ & $8.24 \pm 0.67$ & $7.43 \pm 0.28$ \\
\hline
\end{tabular}

$\mathrm{T} 0=$ time before treatments, $\mathrm{T} 1=1 \mathrm{~h}$ after administration of any treatment, $\mathrm{T} 4=4 \mathrm{~h}$ treatments, $\mathrm{T} 8=8 \mathrm{~h}$ after treatments, $\mathrm{T} 12=12 \mathrm{~h}$ after treatments $($ final time); G1 = IM injection of B. alternatus venom + PBS/BSA, G2 = IM injection of B. alternatus venom + tranexamic acid, G3 = IM injection of B. alternatus venom + desmopressin, G4 = IM injection of B. alternatus venom + anti-bothropic serum + tranexamic acid, G5 = IM injection of $B$. alternatus venom + antibothropic serum + desmopressin.

Table 3. Mean values and standard variation of fibrinogen of rabbits experimentally envenomed with Bothrops alternatus treated with anti-bothropic serum, tranexamic acid and desmopressin

\begin{tabular}{|c|c|c|c|c|c|c|}
\hline Test & Time & G1 & G2 & G3 & G4 & G5 \\
\hline \multirow[t]{5}{*}{ FIBR } & T0 & $421.50 \pm 70.75$ & $427.00 \pm 46.50$ & $443.25 \pm 127.75$ & $542.33 \pm 43.11$ & $536.75 \pm 38.25$ \\
\hline & $\mathrm{T} 1$ & $387.00 \pm 99.50$ & $385.25 \pm 38.75$ & $425.50 \pm 85.50$ & $418.25 \pm 34.75$ & $543.00 \pm 33.50$ \\
\hline & $\mathrm{T} 4$ & $413.25 \pm 68.25$ & $418.00 \pm 44.50$ & $463.75 \pm 96.88$ & $454.50 \pm 80.75$ & $538.25 \pm 37.25$ \\
\hline & T8 & $391.00 \pm 83.50$ & $514.50 \pm 76.50$ & $466.75 \pm 49.75$ & $462.50 \pm 35.00$ & $469.75 \pm 105.75$ \\
\hline & $\mathrm{T} 12$ & $434.50 \pm 69.00$ & $489.75 \pm 71.25$ & $475.25 \pm 41.75$ & $522.67 \pm 92.44$ & $469.50 \pm 107.00$ \\
\hline
\end{tabular}

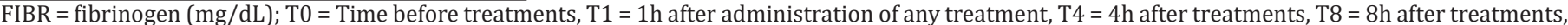

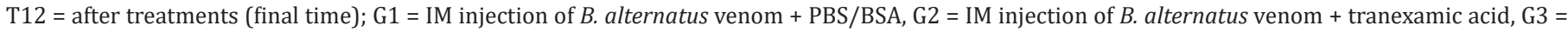

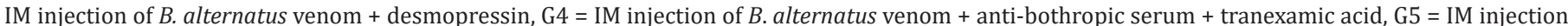
of $B$. alternatus venom + anti-bothropic serum + desmopressin. 
hypercoagulable and mild hypocoagulable states, because they only provide evidence about the commencement of the coagulation process (Wolberg, 2007, Lecut et al. 2015, Duarte et al. 2017). Results obtained from such methods often do not correlate with clinical manifestations (Duarte et al. 2019).

Animals that received B. alternatus venom followed only by PBS/BSA (G1) had lowest Peak and ETP, associated with highest ttPeak. These results suggest that the generation of thrombin is not only delayed, but also reduced 8 and 12 hours after the envenomation prevailing the state of hypocoagulability, also observed by systemic hemorrhages described in histopathological findings. In the present study, a pool of samples was required due to the difficulties in sample collection.

Hypocoagulability is the result of the interaction between venom components, platelets and coagulation cascade. Although defibrinogenation is commonly described in other accidents caused by snakes from Bothrops genus (Costa et al. 2007, Sanchez et al. 2017), the present work showed no significant alterations in fibrinogen content. Primarily thrombin-like enzymes, such as balterobin, are associated with the conversion of fibrinogen into fibrin, initially increasing coagulation potential, leading to further fibrinogen consumption and hypocoagulability state (Gould et al. 1990). This however does not seem to correspond to our results, indicating that decreased hemostasis potential could be associated with other components of the venom. Several substances present in the venom may alter coagulation cascade, such as serine proteinases (thrombin like enzymes, fibrin(ogen)olytic enzymes, activators of prothrombin, factors $\mathrm{V}, \mathrm{VII}$, and X, protein C, platelet aggregation and plasminogen) and metalloproteinases (prothombin and FX activators, fibrin(ogen)olytic enzymes, inhibitors of platelet aggregation and haemorrhagins). Other important components that may also affect hemostasis are phospholipases A2, L-amino acid oxidases, 50-nucleotidases, disintegrins, C-type lectin like proteins and three finger toxins (Perchuc et al. 2005, Sajevic et al. 2011, McCleary \& Kini 2013).

Two main substances could be responsible for such hemostasis alterations, bothroalternin and alternagin. In vitro studies indicate that bothroalternin is a partial inhibitor of thrombin effects on platelet aggregation (Smolka et al. 1998), similar to bothrojaracin. It is known that bothrojaracin prevents

Table 4. Thrombin generation of rabbits experimentally envenomed with Bothrops alternatus treated with antibothropic serum, tranexamic acid and desmopressin eight hours after treatments compared with control group using $1 \mathrm{pM}$ of tissue factor

\begin{tabular}{ccccccc}
\hline Parameters & Control & G1 & G2 & G3 & G4 & G5 \\
\hline Lagtime (min) & 2.13 & 2.80 & 2.80 & 3.47 & 2.13 & 2.47 \\
ETP (nM•min) & 390.79 & 254.49 & 282.52 & 287.41 & 293.41 & 301.65 \\
Peak (nM) & 117.52 & 62.52 & 54.34 & 58.72 & 59.39 & 70.79 \\
ttPeak (min) & 4.47 & 5.14 & 4.81 & 6.14 & 5.47 & 4.81
\end{tabular}

Lagtime (min) = time until the start of thrombin generation, ETP $=$ endogen thrombin potential, Peak = height $(\mathrm{nM}), \mathrm{ttPeak}=$ time to peak; G1 = IM injection of B. alternatus venom + PBS/BSA, G2 = IM injection of $B$. alternatus venom + tranexamic acid, G3 = IM injection of B. alternatus venom + desmopressin, G4 = IM injection of B. alternatus venom + antibothropic serum \pm tranexamic acid, G5 = IM injection of B. alternatus venom + anti-bothropic serum + desmopressin. clotting activity, thrombin-induced platelet activation, thrombin binding to thrombomodulin and hirudin as well as thrombin interaction with antithrombin III-heparin complex (Arocas et al. 1996, Zingali et al. 2005). These inhibitory effects are most likely potentiated by SMVPs. Alternagin, a disintegrin-like protein isolated and characterized from B. alternatus venom, is synthesized from a metalloproteinase precursor from which it is released after proteolytic processing. Alternagin exerts cytotoxic activity, especially in platelets, reducing aggregation (Selistre-de-Araújo et al. 2005). Metalloproteinases detected in other snake species from the genus, such as hemorrhagin BlaH1 and jararhagin exert damage to microvasculature and inhibition of platelet aggregation causing local and systemic hemorrhage, contributing to hypocoagulability state (Stroka et al 2005, Moura-da-Silva et al. 2012).

Treatments using only tranexamic acid (G2) and in association with antivenom (G4) did not show significant improvements whilst comparing to negative control plasma and positive control group (G1). Tranexamic acid is an antifibronolytic agent that interferes with plasminogen interaction with fibrin, necessary to plasmin activation ( $\mathrm{Ng}$ et al. 2015). Activated plasmin is responsible to fibrin degradation and therefore represents the basis of fibrinolysis (Chapin \& Hajjar 2015). Tranexamic acid is often used in emergency surgeries involving trauma and hyperfybrinolysis (Ng et al. 2015). Nonetheless, the present study demonstrates that the dose of venom used in rabbits was not responsible for fibrinogen consumption, and consequently hyperfybrinolysis, which leads to the conclusion that tranexamic acid is not an effective treatment in such conditions. Necropsy and histology findings also corroborate to this statement, as no major differences were observed between groups.

Desmopressin is a vasopressin analogue that potentially contributes to increase factor VIII and von Willebrand factor of the coagulation cascade hence increasing coagulation potential (Ozgonenel et al. 2007). Group G5, that received both desmopressin and antivenom therapy showed results similar to other groups. However, G3 that only received venom and desmopressin showed the highest results in lagtime, both at eight and 12 hours after envenomation, with greater ttPeak at T12 and decreased overall thrombin generation (ETP and Peak). These results show that desmopressin therapy following bothropic envenomation could potentially aggravate

Table 5. Thrombin generation of rabbits experimentally envenomed with Bothrops alternatus treated with antibothropic serum, tranexamic acid and desmopressin twelve hours after treatments compared with control group using $1 \mathrm{pM}$ of tissue factor

\begin{tabular}{ccccccc}
\hline Parameters & Control & G1 & G2 & G3 & G4 & G5 \\
\hline Lagtime (min) & 3.0 & 3.33 & 3.67 & 6.0 & 3.0 & 3.0 \\
ETP (nM•min) & 389.38 & 221.44 & 189.71 & 91.9 & 220.35 & 321.21 \\
Peak (nM) & 95.2 & 52.49 & 33.02 & 11.06 & 28.64 & 37.34 \\
ttPeak (min) & 5.67 & 5.67 & 6.33 & 10.33 & 7.0 & 7.67
\end{tabular}

A pool of four animals from each group was used; Lagtime $(\mathrm{min})=$ time until the start of thrombin generation, ETP = endogen thrombin potential, Peak = height $(\mathrm{nM}), \mathrm{ttPeak}=$ time to peak; G1 = IM injection of $B$. alternatus venom + PBS/BSA, G2 = IM injection of B. alternatus venom + tranexamic acid, G3 = IM injection of B. alternatus venom + desmopressin, G4 = IM injection of B. alternatus venom + anti-bothropic serum + tranexamic acid, G5 = IM injection of $B$. alternatus venom + anti-bothropic serum + desmopressin. 
hypocoagulability state, as it prolongs time to thrombin generation initiation, time to reach its' full potential and reduces overall thrombin generation. The pathogenesis of these results is not fully understood, as treatment in association with antibothropic serum showed much milder results. It is possible that vasoconstriction contributes to further hemorrhage and coagulation disturbances. Necropsy and histology findings however did not show important differences when comparing desmopressin treatments to other groups.

\section{CONCLUSIONS}

Bothrops alternatus venom induces hypocoagulability stage characterized by thrombin generation by CAT method for the first time.

Administration of tranexamic acid and desmopressin did not show significant improvement in tests results and tissue damage; in fact, desmopressin treatment seems to decrease thrombin generation.

Acknowledgments.- We thank the "Fundação Ezequiel Dias" (FUNED) for providing anti-bothropic serum.

Funding.- This study received financial support from "Conselho Nacional de Desenvolvimento Científico e Tecnológico" (CNPq). Process number: 305617/2017-6.

Conflict of interest statement.- The authors declare that they have no competing interest.

\section{REFERENCES}

Arocas V., Zingali R.B., Guillin M.C., Bom C. \& Jandro-Perrus M. 1996. Bothrojaracin: a potent two-site-directed thrombin inhibitor. Biochemistry 35(28):90839089. <https://dx.doi.org/10.1021/bi960043l><PMid:8703912>

Brasil 2017. Ministério da Saúde. Available at <http://portalarquivos2.saude. gov.br/images/pdf/ 2018/junho/25/1-CasosOfidismo-2000-2017.pdf> Accessed on Sep. 23, 2018.

Bucaretchi F., Herrera S.R.F., Hyslop S., Baracat E.C.E. \& Vieira R.J. 2001. Snakebites by Bothrops spp in children in Campinas, São Paulo, Brazil. Revta Inst. Med. Trop. S. Paulo 43(6):329-333. <https://dx.doi.org/10.1590/ S0036-46652001000600006><PMid:11781603>

Castro H.C., Dutra D.L.S., Oliveira-Carvalho A.L. \& Zingali R.B. 1998. Bothroalterin, a thrombin inhibitor from the venom of Bothrops alternatus. Toxicon 36(12):1903-1912.<https://dx.doi.org/10.1016/s0041-0101(98)00111-1> $<$ PMid:9839674>

Chapin J.C. \& Hajjar A. 2015. Fibrinolysis and the control of blood coagulation. Blood Rev. 29(1):17-24.<https://dx.doi.org/10.1016/j.blre.2014.09.003> <PMid:25294122>

Costa J.O., Petric C.B., Hamaguchi A., Homsi-Brandeburgo M.I., Oliveira C.Z., Soares A.M. \& Oliveira F. 2007. Purification and functional characterization of two fibrinogenolytic enzymes from Bothrops alternatus venom. J. Venom Anim. Toxin. Incl. Trop. Dis. 13(3):640-654. <https://dx.doi.org/10.1590/ S1678-91992007000300007>

Deloughery T.G. 2015. Clinical dilemmas in anticoagulation: extremes of weight, renal disease, recent bleeding and surgery, p.179-185. In: Ibid. (Ed.), Hemostasis and Thrombosis. 3rd ed. Springerlink, Switzerland.

Duarte R.C.F., Ferreira C.N.R., Alves D.R., Reis H.J. \& Carvalho M.G. 2017. Thrombin generation assays for global evaluation of the hemostatic system: perspectives and limitations. Revta Bras. Hematol. Hemoter. 39(3):259265. <https://dx.doi.org/10.1016/j.bjhh.2017.03.009>

Duarte R.C.F., Rios D.R.A., Leite P.M., Alves L.C., Magalhães H.P.B. \& Carvalho M.G. 2019. Thrombin generation test for evaluating hemostatic effects of
Brazilian snake venoms. Toxicon 163:36-43. <https://dx.doi.org/10.1016/j. toxicon.2019.03.012><PMid:30880188>

Espitia O. \& Fouassier M. 2015. Le test de génération de thrombine. Rev. Med. Interne 36(10):690-693. <https://dx.doi.org/10.1016/j.revmed.2015.04.013>

Garcia-Denegri M.E., Teibler G.P., Maruñak S.L., Hernández D., Acosta O.C. \& Leiva L.C. 2016. Efficient muscle regeneration after highly haemorrhagic Bothrops alternatus venom injection. Toxicon 122:167-175. <https://dx.doi.org/10.1016/j.toxicon.2016.10.005>

Gould R.J., Polokoff M.A., Friedman P.A., Huang T.F., Holt K.C., Cook J.J. \& Niewiarowski S. 1990. Disintegrins: a family of integrin inhibitory proteins from Viper venoms. Proc. Soc. Exp. Biol. Med. 195(2):168-171. <https://dx.doi.org/10.3181/00379727-195-43129b ><PMid:2236100>

Gutiérrez J.M., Escalante T. \& Rucavado A. 2009. Experimental pathophysiology of systemic alterations induced by Bothrops asper snake venom. Toxicon 54(7):976-987. <https://dx.doi.org/10.1016/j.toxicon.2009.01.039> $<$ PMid:19303034>

Hemker H.C., Giesen P., AI Dieri R., Regnault V., de Smedt E., Wagenvoord R., Lecompte T. \& Béguin S. 2003. Calibrated automated thrombin generation measurement in clotting plasma. Pathophysiol. Haemost. Thromb. 33:4-15. <https://dx.doi.org/10.1159/000071636><PMid:12853707>

Horstman L.L., Valle-Riestra B.J., Jy W., Wang F., Mao W. \& Ahn Y.S. 1995. Desmopressin (DDAVP) acts on platelets to generate platelet microparticles and enhanced procoagulant activity. Thromb. Res. 79(2):163-174. <https://dx.doi.org/10.1016/0049-3848(95)00102-w><PMid:7676403>

Lecut C., Peters P., Massion P.B. \& Gothot A. 2015. Is there a place for thrombin generation assay in routine clinical laboratory? Ann. Biol. Clin., Paris, 73(2):137-149. <https://dx.doi.org/10.1684/abc.2014.1018> $<$ PMid:25847735>

Mamede C.C.N., Sousa B.B., Pereira D.F., Matias M.S., Queiroz M.R., Morais N.C., Vieira S.A., Stanziola L. \& Oliveira F. 2016. Comparative analysis of local effects caused by Bothrops alternatus and Bothrops moojeni snake venoms: enzymatic contributions and inflammatory modulation. Toxicon 117:37-45. <https://dx.doi.org/10.1016/j.toxicon.2016.03.006>

McCleary R.J.R. \& Kini M. 2013. Snake bites and hemostasis/thrombosis. Thromb. Res.132(6):642-646.<https://dx.doi.org/10.1016/j.thromres.2013.09.031> <PMid:24125598>

McCormack P.L. 2012. Tranexamic acid: a review of its use in the treatment of hyperfibrinolysis. Drugs 72(5):585-617. <https://dx.doi. org/10.2165/11209070-000000000-00000><PMid:22397329>

Miranda C.A.S.F., Cardoso M.G., Mansanares M.E., Gomes M.S. \& Marcussi S. 2014. Preliminary assessment of Hedychium coronarium essential oil on fibrinogenolytic and coagulant activity induced by Bothrops and Lachesis snake venoms. J. Venom. Anim. Toxin. Incl. Trop. Dis. 20:39. <https:// dx.doi.org/10.1186/1678-9199-20-39>

Moura-da-Silva A.M. \& Baldo C. 2012. Jararhagin, a hemorrhagic snake venom metalloproteinase from Bothrops jararaca. Toxicon 60(3):280-289. <https://dx.doi.org/10.1016/j.toxicon.2012.03.026><PMid:22534074>

Ng W., Jerath A. \& Wasowicz M. 2015. Tranexamic acid: a clinical review. Anaesthesiol. Intensive Ther. 47(4):339-350. <https://dx.doi.org/10.5603/ AIT.a2015.0011 > <PMid:25797505>

Núñez V., Otero R., Barona J., Saldarriaga M., Osorio R.G., Fonnegra R., Jiménez S.L., Díaz A. \& Quintana J.C. 2004. Neutralization of the edema-forming, defibrinating and coagulant effects of Bothrops asper venom by extracts of plants used by healers in Colombia. Braz. J. Med. Biol. Res. 37(7):969977. <https://dx.doi.org/10.1590/S0100-879X2004000700005> $<$ PMid:15264003>

Ozgonenel B., Rajpurkar M. \& Lusher J.M. 2007. How do you treat bleeding disorders with desmopressin? Postgrad. Med. J. 83(977):159-163. <https://dx.doi.org/10.1136/pgmj.2006.052118><PMid:17344569>

Pabinger I., Fries D., Schöchl H., Streif W. \& Toller W. 2017. Tranexamic acid for treatment and prophylaxis of bleeding and hyperfibrinolysis. Wien 
Klin Wochenschr. 129(9/10):303-316. <https://dx.doi.org/10.1007/ s00508-017-1194-y><PMid:28432428>

Perchuc A.M., Menin L., Stocklin R., Buhler B. \& Schoni R. 2005. The potential of Bothrops moojeni venom in the filed of hemostasis. Established use and new insights. Pathophysiol. Haemost. Thromb. 34(4/5):241-245. <https://dx.doi.org/10.1159/000092431><PMid:16707935>

Rocha M.M.T. \& Furtado M.F.D. 2005. Caracterização individual do veneno de Bothrops alternatus Duméril, Bibron \& Duméril em função da distribuição geográfica no Brasil (Serpentes, Viperidae). Revta Bras. Zool. 22(2):383393. <https://dx.doi.org/10.1590/S0101-81752005000200012>

Sajevic T., Leonardi A. \& Krizaj I. 2011. Haemostatically active proteins in snake venoms. Toxicon 57(5):627-645. <https://dx.doi.org/10.1016/j. toxicon.2011.01.006> <PMid:21277886>

Sanchez E.F., Flores-Ortiz R., Alvarenga V.G. \& Eble J.Á. 2017. Direct fibrinolytic snake venom metalloproteinases affecting hemostasis: structural, biochemical features and therapeutic potential. Toxins 9(12):E392. <https://dx.doi. org/10.3390/toxins9120392><PMid:29206190>

Sano-Martins I.S., Fan H.W., Castro S.C., Tomy S.C., Franca F.O., Jorge M.T., Kamiguti A.S., Warrel D.A. \& Theakston R.D. 1994. Reliability of the simple 20 minute whole blood clotting test (WBCT20) as an indicator of low plasma fibrinogen concentration in patients envenomed by Bothrops snakes. Toxicon 32(9):1045-1050. <https://dx.doi.org/10.1016/00410101(94)90388-3><PMid:7801340>

Selistre-de-Araújo H.S., Cominetti M.R., Terruggi C.H.B., Mariano-Oliveira A., Crepin M., Figueiredo C.C. \& Morandi V. 2005. Alternagin-C, a disentegrinlike protein from the venom of Bothrops alternatus, modulates $\alpha_{2} \beta_{1}$ integrin-mediated cell adhesion, migration and proliferation. Braz. J. Med. Biol. Res. 38(10):1505-1511. <https://dx.doi.org/10.1590/S0100879X2005001000007>

Senise L.V., Yamashita K.M. \& Santoro M.L. 2015. Bothrops jararaca envenomation: Pathogenesis of hemostatic disturbances and intravascular hemolysis.
Exp. Biol. Med. 240(11):1528-1536. <https://dx.doi.org/10.1016/j. blre.2014.09.003><PMid:26080462>

Smolka M.S., Marangoni S., Oliveira B. \& Novello J.C. 1998. Purification and partial characterization of a thrombin-like enzyme, balterobin, from the venom of Bothrops alternatus. Toxicon 36(7):1059-1063. <https://dx.doi. org/10.1016/s0041-0101(98)80008-1><PMid:9690798>

Stroka A., Donato J.L., Bon C., Hyslop S. \& de Araújo A.L. 2005. Purification and characterization of hemorrhagic metalloproteinase from Bothrops lanceolatus (Fer-de-lance) snake venom. Toxicon 45(4):411-420. <https://dx.doi.org/10.1016/j.toxicon.2004.11.010><PMid:15733562>

Suh D.W., Kyung B.S., Han S.B., Cheong K. \& Lee W.H. 2018. Efficacy of tranexamic acid for hemostasis in patients undergoing high tibial osteotomy. J. KneeSurg. 31(1):50-55. <https://dx.doi.org/10.1055/s-0037-1600091> $<$ PMid:28355682>

Vilhardt H., Barth T., Falc J. \& Nilsson I.M. 1987. Plasma concentrations of factor VIII after administration of DDAVP to conscious dogs. Thromb. Res. 47(5):585-591. <https://dx.doi.org/10.1016/0049-3848(87)90363-X> $<$ PMid:3118500>

Wolberg A.S. 2007. Thrombin generation and fibrin clot structure. Blood Rev. 21(3):131-142. <https://dx.doi.org/10.1016/j.blre.2006.11.001> $<$ PMid:17208341>

Wong Y., Low J.A. \& Chio M.T. 2016. Role of tropical tranexamic acid in hemostasis of locally advanced basal cell carcinoma. JAAD Case Rep. 2(2):162-163. <https://dx.doi.org/10.1016/j.jdcr.2016.03.001> <PMid:27222877>

Zingali R.B., Ferreira M.S., Assafim M., Frattani F.S. \& Monteiro R.Q. 2005. Bothrojaracin, a Bothrops jararaca snake venom-derived (pro)thrombin inhibitor, as and anti-thrombotic molecule. Pathophysiol. Haemost. Thromb. 34(4/5):160-173. <https://dx.doi.org/10.1159/000092416> $<$ PMid:16707920> 